\title{
HIGHLY ALUMINOUS XENOLITHS FROM KIMBERLITES OF YAKUTIA: MANTLE PETROLOGY REMARKS
}

\author{
Z. V. Spetsius \\ Institute of Diamond Industry, ALROSA Co. Ltd, Mirny, Russia
}

\section{INTRODUCTION}

Highly aluminous xenoliths include kyanite-, corundum and coesite-bearing eclogites, grospydites and alkremites. These unique xenoliths are present in different kimberlites of Yakutia but more often have been found in the Udachnaya and others pipes of central Daldyn-Alakitsky region. Granulites or eclogitelike rocks with the kyanite and corundum that belong to the xenoliths of the lower crust or transition lower crust - upper mantle zone are present in kimberlites of this field. In all varieties of highly aluminous xenoliths except alkremites and eclogite like rocks are found diamondiferous samples. Some evidence exists that these xenoliths represent a specific group of mantle rocks and could be formed not by the differentiation of primitive mantle but have present the remnants of subducted crust. Petrologic importance of coesitebearing xenoliths is determined by a number of restrictions, which cause their presence on conditions of xenoliths origin and kimberlite formation.

\section{SAMPLES AND ANALYTICAL TECHNIQUES}

More than 200 samples of mantle xenoliths from the kimberlite pipes situated in different parts of Yakutian kimberlite province were studied. Modal analyses have been performed for the major part of xenoliths. For most samples major rock chemistry was determined. Major-element analyses were performed for the rockforming and minor minerals. Trace element composition was obtained for some minerals. All samples were classified into different varieties of eclogites according to their petrographic and chemical features.

Major element compositions of silicate and oxide minerals in the xenoliths were determined with a Superprobe JXA-8800R electron microprobe at the ALROSA Co Ltd. (Mirny) and partly using a CAMECA SX-50 electron microprobe at Institute of Geology (Yakutsk). Part of the rockforming garnets and clinopyroxenes and also different secondary phases of eclogites were investigated by ESM with EDS at the University of Western Australia (Perth). Analytical conditions included an accelerating voltage of $15 \mathrm{keV}$, a beam current of $20 \mathrm{nA}$, beam size of $5 \mu \mathrm{m}$, and 20 seconds counting time for all elements. All analyses underwent a full ZAF correction.

The trace elements (TRE) have been measured in rockforming and some secondary minerals of eclogites by laser Ablation ICP-MS (LAM) at the RSES of Australian National University, Canberra, using NIST 610 glass as external standard and $\mathrm{Ca}$ as internal standard.

\section{RESULTS}

The petrographic peculiarities of kyanite eclogites showed, that among them two rock groups of different structure and chemical composition can be distinguished: fine- and mediumgrained with mosaic structure and coarse-grained rocks with broken down structure. Eclogites with mosaic structure are characterized by medium-grained constitution, banding and occurrences of symplektitic intergrowths of garnet with kyanite, clinopyroxene and coesite. In a number of samples, later development of kyanite is fixed. Only in this group the grospydites were found. In broken down kyanite eclogites, coarse-grained coesite with the size, corresponding to that of the other rockforming minerals occurs. They are characterized by higher $\mathrm{Na} / \mathrm{K}$ and $\mathrm{Fe}^{3+} / \mathrm{Fe}^{2+}$ ratio, as well as high contents of $\mathrm{Na}_{2} \mathrm{O}$ and $\mathrm{CaO}$.

Highly aluminous xenoliths differ from bimineral eclogites in their high content of $\mathrm{Al}_{2} \mathrm{O}_{3}$ and total alkali content. Coesite-bearing varieties are characterized by low $\mathrm{MgO}$ content and high $\mathrm{Na}_{2} \mathrm{O} / \mathrm{K}_{2} \mathrm{O}$ ratio.Geochemical peculiarities of kyanite eclogites and other rocks exhibit themselves in a sloping chondritenormalized distribution of rare earth element in garnets, in contrast to bimineral rocks, as well as in bw $\mathrm{Y} / \mathrm{Zr}$ ratio. Preliminary data for the trace elements that were taken by dissolution on garnet separates from alkremites and analysed by quadrupole ICP-MS at Durham University suggest an extremely high the ${ }^{176} \mathrm{Lu} /{ }^{177} \mathrm{Hf}$ ratio $(>20)$ at least for one sample (Nowell et al., this volume).

\section{MINERALOGY OF HIGLY ALUMINOUS XENOLITHS}

The mineralogy of the eclogite-like rocks with the kyanite is not so variable as eclogites. Main minerals are garnet and clinopyroxene with addition of 
secondary formed clinopyroxene and kyanite in intergrowths (Fig.1). Representative compositions of all minerals are given in table 1 .

\section{Table 1: Major analyses of minerals of eclogite-like xenolith with kyanite from the Udachnaya (sample U-2295).}

$\begin{array}{lcccccr} & \mathrm{Gt}(1) & \mathrm{Pl}(2) & \mathrm{Cpx}(3) & \mathrm{Ky}(4) & \mathrm{Px}(5) & \mathrm{Gt}(6) \\ \mathrm{SiO}_{2} & 41.35 & 52.31 & 50.29 & 36.51 & 52.6 & 41.39 \\ \mathrm{TiO}_{2} & 0.1 & 0.03 & 0.56 & 0.05 & 0.1 & 0.03 \\ \mathrm{Al}_{2} \mathrm{O}_{3} & 22.75 & 29.82 & 10.26 & 61.31 & 5.13 & 22.75 \\ \mathrm{Cr}_{2} \mathrm{O}_{3} & 0.14 & 0.05 & 0.34 & 0.22 & 0.41 & 0.3 \\ \mathrm{FeO} & 12.19 & 0.03 & 2.25 & 0.39 & 2.26 & 12.13 \\ \mathrm{MnO} & 0.14 & 0.02 & 0.03 & 0.07 & 0.13 & 0.14 \\ \mathrm{MgO} & 14.05 & 0.14 & 12.26 & 0.16 & 14.61 & 11.71 \\ \mathrm{CaO} & 9.1 & 12.75 & 22.25 & 0.05 & 22.6 & 10.75 \\ \mathrm{Na} 2 \mathrm{O} & 0.08 & 4.69 & 1.66 & 0.04 & 1.84 & 0.32 \\ \mathrm{~K}_{2} \mathrm{O} & 0.01 & 0.23 & 0.02 & 0.01 & 0.03 & 0.02 \\ \text { Total } & 99.91 & 99.84 & 99.92 & 98.81 & 99.71 & 99.54 \\ \end{array}$

Numbers in parenthesis answer to the points of analyses on Fig. 1

\section{Eclogite xenoliths}

Clinopyroxene in kyanite eclogites is characterized by high $\mathrm{Mg \# ,} \mathrm{high-Al} \mathrm{content} \mathrm{and} \mathrm{typical} \mathrm{omphacite.} \mathrm{Clear}$ correlation of jadeite content in omphacites of eclogites exists with both bimineral and with kyanite, along with their $\mathrm{Al}_{2} \mathrm{O}_{3}$ and $\mathrm{CaO}$-content, and therewith this relationship is maintained in eclogite clinopyroxenes from all the pipes (Spetsius and Serenco, 1990). The comparison of eclogite clinopyroxenes from pipes Mir, Obnazhonnaya and Udachnaya shows that the clinopyroxenes of the last have more variable composition that is caused by the absence of eclogites of high-Al line in the first two pipes. The examination of eclogites from pipe Udachnaya indicates the enrichment of omphacites by lithophile trace elements and that, perhaps, the result of the action of metasomatic fluids (Spetsius, 1995).

Garnet from highly aluminous xenolits has a wide variation in Fe-, $\mathrm{Mg}$ - and $\mathrm{Ca}$-content. Garnets of these xenoliths differ by higher $\mathrm{Ca \#}$ according to the garnets from bimineral eclogites and usually have high $\mathrm{Mg \# \text {. }}$ They contain over than 40 mol.\% of pyrope, 10-20 mol.\% of almandine and variable (20-60 mol.\%) of grossular components. The high- $\mathrm{Cr}$ garnets containing up to $1.0 \mathrm{wt} \%$ of $\mathrm{Cr}_{2} \mathrm{O}_{3}$ are found in some kyanite eclogites. Wide range of content of $\mathrm{Ca}, \mathrm{Mg}, \mathrm{Fe}, \mathrm{Cr}$ and $\mathrm{Ti}$ is typical to garnets from xenoliths of eclogite suite taken even from one pipe (Spetsius and Serenco, 1990). The garnets from kyanite eclogites of Udachnaya vary
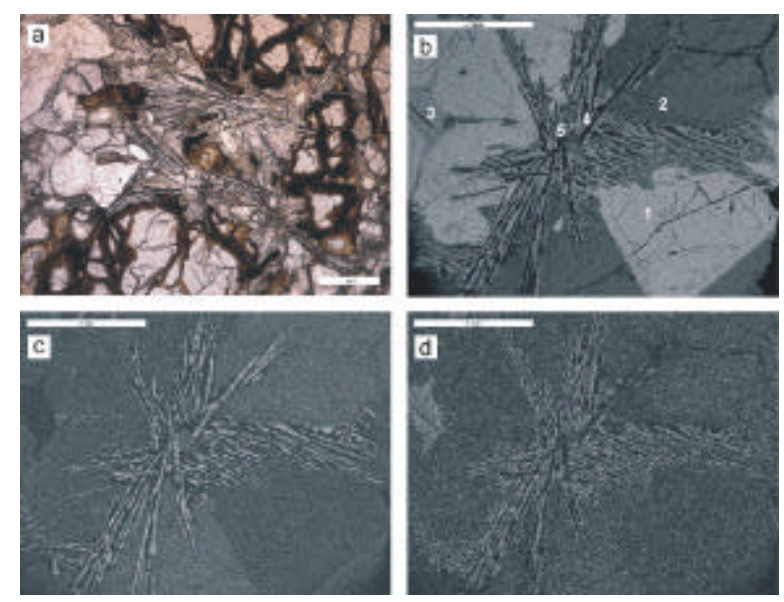

Figure 1: Kyanite-bearing eclogitelike xenoliths from the kimberlites of Yakutia. Plane-polarized light - a (intergrowths of Cpx and Ky between grains of Gt and Plag are obvious, sample Zr-18 from Zarnitsa pipe); b, d and c scanning electron microscope images of eclogitelike rock xenoliths from the kimberlite pipe Udachnaya: a - backscattered image of Ky-Cpx intergrowth (Sample U-2295), c and $\mathrm{d}$ - images in $\mathrm{Al} \mathrm{K}_{\alpha}$ and $\mathrm{Ca} \mathrm{K}_{\alpha}$. Points of microprobe analyses of minerals are shown (see data in Table 1).

widely in $\mathrm{Ca} / \mathrm{Ca}+\mathrm{Mg}$ from 22 to $76 \%$. The most calcic samples $(>50 \% \mathrm{Ca \# )}$ are thus a grospydites. There are fixed rather less variations in Ca\# of eclogite garnets from the Mir pipe where these xenoliths are absent.

Kyanite differs by euhedral and "fresh" outlook from the other rock-forming minerals, except in rare cases, when it is replaced by corundum and mullite. There are two recognized types of kyanite: 1) crystals of tabular shape, of macroscopic blue color, sometimes with greenish tint (chrome containing); 2) needle-shaped colorless kyanite, typical for eclogite-like rocks sometimes occurring in kyanite eclogites where it is the latest. In some samples, there are fixed symplectite intergrowths of kyanite with garnet.

Coesite is found in more than 20 samples of kyanite eclogites and grospydites from the Udachnaya pipe were he was firstly discovered in mantle xenoliths (Ponomarenko et al., 1977). The abundance of coesite ranges from trace quantities (single grains and inclusions) to approximately $10 \%$ by volume. Grospydites with coesite from Zagadochnaya pipe are described also. According to the conditions of occurrence, three varieties of coesite are detected: a) subhedral coesite grains with the size $1.0-3.0 \mathrm{~mm}$; b) coesite inclusions in the rockforming eclogite minerals; c) subgraphic intergrowths with garnet (Fig.2). The presence and preservation of coesite in eclogites indicate both high pressure of their formation (more than $30 \mathrm{kbar}$ ) and sets a number of limitations on the timing of xenoliths cooling while trapping and elevating them on the surface by kimberlitic magma. 

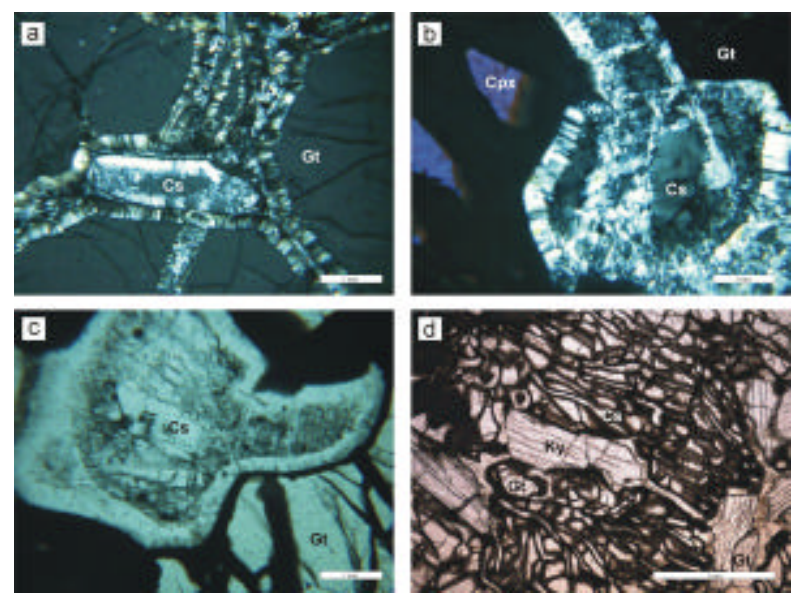

Figure 2: Coesite-bearing eclogite xenoliths from the Udachnaya kimberlite pipe. Crossed polarizers $-\mathrm{a}, \mathrm{b}$, and $\mathrm{c}$, $\mathrm{d}$ - plane-polarized light. Legend for these and next photomicrographs is as follows: $\mathrm{Gt}=$ garnet, $\mathrm{Cpx}=$ clinopyroxene, $\mathrm{Cs}=$ coesite, $\mathrm{Ky}=$ kyanite, $\mathrm{Cd}=$ corundum. (a) View of coesite relict with pronounced palisade texture of surrounding secondary quartz between grains of garnet (Sample U-2290). (b) and (c) Relicts of coesite surrounded by rims of palisade quartz with addition of fine grained quartz (Sample U-256). (d) Intergrowth of coesite with garnet (Sample U-168).

Corundum is present in the form of small needles 0.01$0.2 \mathrm{~mm}$ long. Usually corundum replaces kyanite (Fig. $3 a)$, and more rarely forms separate lamellar crystals up to $2 \mathrm{~mm}$ in kyanite eclogites. It has a dark-blue color and is referred to as sapphire. In some eclogites, the corundum is ruby-red in color and forms elongated crystals up to $1-3 \mathrm{~mm}$. Such corundum present in diamondiferous samples that contains more than $90 \%$ of garnet in the rock (Fig. 3b). It is more likely that corundum has a secondary origin in this case also. In their compositions these samples close to the xenoliths described as corganites by Massone and Haggerty (1989).

Diamondiferous samples have been found in all varieties of these xenoliths except alkremites. Usually kyanite eclogites from the Udachnaya pipe contain cubic or coated diamonds which are small in size in most cases. There exist some evidence about their secondary metasomatic origin after rock formation by introduction of fluids enriched in $\mathrm{H} 2 \mathrm{O}$ and other volatile components (Spetsius, 1999). New discovering of two samples corundum-bearing eclogites with diamonds from the Udachnaya pipe is not consist with this origin because the xenoliths contain large diamonds that are present by plane octahedron crystals (Fig. 3 d, e). Besides, diamonds show obvious features of dissolving and resorption in one sample (Fig. 3d). By their petrography, mineral composition and geochemistry these two newly discovering samples of corundum-bearing eclogites with diamonds from the Udachnaya pipe are close to granatites from this pipe. It should be noted that rather obvious secondary formation of corundum as fixed in thin section and not excluded secondary late diamond origin as well.

\section{DISCUSSION}

Highly aluminuous xenoliths are rather common among the eclogite xenolith suite from many pipes of Yakutian province; especially in kimberlites of Daldyn-Alakitsky region. By their petro- and geochemistry these rocks belong to the group $\mathrm{C}$ eclogites. Aside from the presence of coesite or corundum, there are no apparent differences in texture of xenoliths and major chemistry of garnets and clinopyroxenes. Besides, most xenoliths of this suite contain kyanite. Coesite is present in silica over-saturated and corundum in silica under-saturated rocks. The presence of coesite implies that the eclogites from kimberlites must have been subducted to the depth greater than $100 \mathrm{~km}$, at pressures in excess of $3 \mathrm{GPa}$ (Spetsius and Serenco, 1990 and reference therein). It should be pointed that there are present only rare estimations for oxygen isotope composition of garnet from these rocks, but values of the $\delta^{18} \mathrm{O}$ are in the range 4.5-7.0\% $\%$. These data are in accord with the oxygen isotope estimation for garnets of coesite eclogites from Roberts Victor (Shulze at al., 2000) and provide strong evidence on their possible origin as the products of oceanic crust subduction.
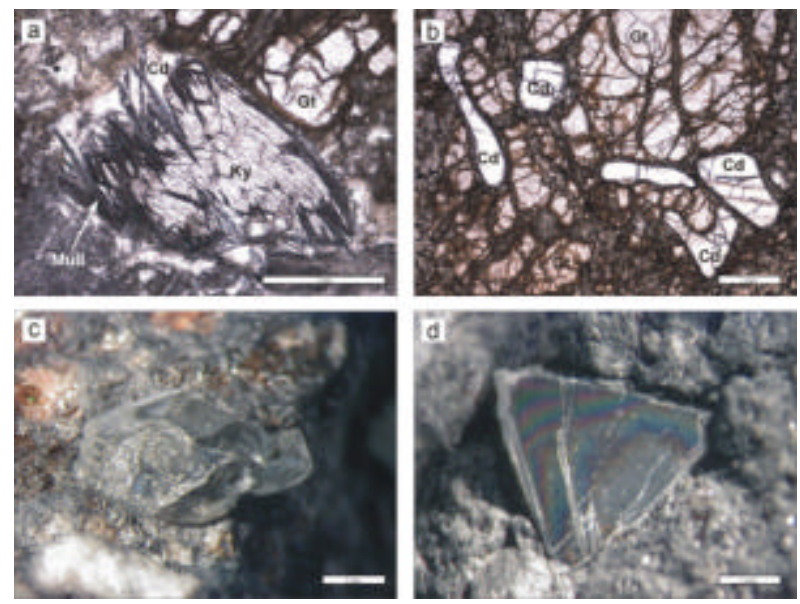

Figure 3: Diamonddiferous corundum-bearing eclogite xenoliths from the Udachnaya kimberlite pipe. Planepolarized light - a, b, and c, d-microphotographs.

(a) Needles of secondary corundum sapphire variety in association with mullite replacing kyanite (Sample U-820). (b) Corundum of ruby variety in diamondiferous granatite (Sample Ud-114). (c) Intergrowth of two octahedron diamonds in corundum-bearing eclogite. Resorption texture on the bigger crystal is obvious (Sample Ud-155). (d) Planefaced octahedron in corundum-bearing granatite. (Sample Ud-114). 
It is possible to use well-known representatives of mantle: xenoliths and diamonds to estimate the distribution of subducted crustal remnants in the upper mantle underlying the Siberian platform. There have been checks on the populations of mantle xenoliths from the main well investigated kimberlite pipes of the Yakutian province. For this purpose also we can use published data and estimate of the distribution of light isotope diamonds in diamond populations from different kimberlite pipes. The carbon isotopic ratios of diamonds from the Yakutian kimberlites have shown that many diamonds have $\ddot{a}^{13} \mathrm{C}$ distinct from the typical mantle value (e.g., Bulanova et al., 1999; Galimov, 1991). The reasonable explanation for the high $\ddot{a}^{13} \mathrm{C}$ is a contribution from the subducted oceanic crust. These results show that in many pipes kyanite eclogites or isotopically light diamonds are present, or both. The presence and preservation of coesite in eclogites gives a strong proof of the involvement of oceanic crust in subduction by the SCLM formation.

The study of xenoliths in kimberlite from pipes of Yakutian province points to obvious differences in their distribution in separate pipes and fields (Spetsius, 1995). Comparison of eclogite suite xenoliths on the profile from the south to the north of province (about 1000 kilometers) showed that there is a lateral mantle heterogeneity. It is expressed by the presence only in central part of the province of a suite of the highaluminous rocks in kimberlite pipes of DaldynAlakitsky field. Such xenoliths were found in pipes Udachnaya, Zagadochnaya, Zarnitsa and others. It should be noted that these mantle xenoliths are coupled with some crustal granulite xenoliths such as eclogitelike rocks containing sometimes kyanite in their composition.

It is possible to speculate from petrologic evidence that some eclogites are products of subducted oceanic crust. This is confirmed for the coesite-bearing and diamondiferous eclogites from kimberlites of Yakutia (e.g., Jacob et al., 1994). According to the distribution of different types of eclogites and the presence of isotopically light as well cubic crystals of diamonds in kimberlites of Yakutian province it is possible to estimate the addition of crustal sources in the mantle under Siberian platform. In the central part of Siberian platform the remnants of subducted crust could be about 5-10\% of whole rocks of the upper mantle. If we assume that all isotopic light diamonds were crystallized in remnants of subduction crust we could use this for the estimation of contribution of subducted oceanic crust in formation of the SCLM of Siberian platform. According these data about $10 \%$ of diamond population from kimberlites of Yakutia were originated in subducted rocks.

There are two possible ways of formation of the highly aluminous eclogites: (i) as a result of transformation of initial rocks of gabbro-anorthosite composition through the intermediate stage of eclogite-like rocks in process of subduction or delamination; (ii) as a result of fractional crystallization in mantle conditions of ultramafic melts. The first way is proved by petrographic, petrochemical and isotopic investigations that show genetic relationship of all the series of these rocks (Spetsius and Serenco, 1990). The second way is proved by the presence of subsolidus changes in eclogites and by continuous sets of high aluminous xenoliths from kyanite eclogites up to alkremites and by linear differentiation trends of their compositions (Spetsius, 1995). Such diversity of their origin and also the following evolution of eclogites in the process of partial melting and mantle metasomatism, which have been considered in a number of papers (Spetsius, 1995; Spetsius and Serenco, 1990; Spetsius and Taylor, 2003 and references therein), in their turn, determine the specific nature of these rocks in separate pipes.

Based on highly enriched $\mathrm{Sr}$ isotope composition $(87 \mathrm{Sr} / 86 \mathrm{Sr}>0.8)$, a crustal origin was proposed for alkremites whereby these rocks could represent the restites from subducted, melted pelitic sediments (Massone \& Haggerty, 1989). The preliminary data on trace element content in garnet and high Lu/Hf ratio do not support this model (Nowell et al., this volume). It is more likely that these rocks were formed as a result of the fractionation by melting of the lithosphere as was suggested first by A. Ponomarenko (1977). In our opinion, at least part of alkremites is formed as a result of fractional crystallization of ultramafic melts enriched in $\mathrm{Al}$ and $\mathrm{Mg}$ and probably these unique rocks could represent a residual melt after earlier separation some kyanite eclogites

\section{CONCLUSIONS}

A specific rock group, including kyanite and coesite eclogites and alkremites, represents mantle xenoliths of highly aluminous rocks in kimberlites. The wide abundance of these types of xenoliths in the central region of Yakutian kimberlite province points at the lateral petrographic heterogeneity of SCLM under Siberian craton. The confinement of cubic diamonds to highly aluminous rocks also determines the lateral heterogeneity in morphology of diamonds population from the south to the north of the province. Two possible ways of formation of highly aluminous rocks could be proposed.

A coupled data on oxygen isotope of eclogite minerals and carbon isotope of diamonds give a strong support that subduction of oceanic crust had have a place in time of formation of underlying mantle roots under Yakutian kimberlite province of Siberian platform especially its central part. Presence of $\mathrm{Ky}$ - and Cs- 
bearing eclogites in kimberlite as well as light isotopic diamonds and cubic crystals in diamonds population could be used for estimation of the intensity of the subduction process in time of the SCLM formation beneath any given kimberlite pipe or field.

\section{REFERENCES}

Bulanova, G.P., Pearson, D.G., Hauri, E.H, Griffin, B.J., 2002. Carbon and nitrogen isotope systematics within a sector-growth diamond from the Mir kimberlite, Yakutia. Chem. Geol. 188, 105-123.

Bulanova, G.P., Griffin, W.L., Kaminsky, F.V., Davies, R., Spetsius, Z.V., Ryan, C.G., Andrew, A., Zahkarchenco, O.D., 1999. Diamonds from Zarnitsa and Dalnaya kimberlites (Yakutia), their nature and lithospheric mantle source. The $7^{\text {th }}$ IKC proceeding, v. 1, Cape Town, South Africa, pp. 49-56.

Galimov, E.M., 1991. Isotope fractionation related to kimberlite magmatism and diamond formation. Geochim. Cosmochim. Acta. 55, 1697-1708.

Jacob, D., Jagoutz, E., Lowry, D., Mattey, D., Kudrjavtseva, G., 1994. Diamondiferous eclogites from Siberia: Remnants of Archean oceanic crust. Geochim. Cosmochim. Acta. 58, 5191-5207.

Massone, P., Haggerty, S.E., 1989. Peraliminous xenoliths in kimberlite: Metamorphosed restites produced by partial melting of pelites. Geochim. Cosmocim. Acta. 53, 151-156.

Ponomarenko, A.I., Sobolev, N.V., Pokhilenko, N.P., 1976. Diamondiferous grospydite and diamondiferous disthen eclogites from kimberlite pipe Udachnaya, Yakutia. Dokl. Akad. Nauk SSSR. 226(4), 927-930 (in Russian)

Ponomarenko, A.I., Leskova N.V., 1980. Peculiarities of chemical composition of minerals of alkremites from kimberlite pipe "Udachnaya". Dokl. Akad. Nauk SSSR. 252(3), 707-711 (in Russian).

Ponomarenko, A.I., Spetsius, Z.V., Lybushkin, V.A., 1977. Kyanite eclogite with coesite. Dokl. Akad. Nauk SSSR. 236(1), 215-219 (in Russian)

Snyder, G.A., Jerde, E.A, Taylor, L.A., Halliday, A.N., Sobolev, V.N., Sobolev, N.V., 1993. Nd and Sr isotopes from diamondiferous eclogites, Udachnaya Kimberlite Pipe, Yakutia, Siberia: Evidence of differentiation in early Earth? Earth Planet Sci. Lett. 118, 91-100

Spetsius, Z. V., 1995. Occurrence of diamond in the mantle: a case study from the Siberian Platform. J. Geochem. Explor. 53, 25-39.

Spetsius, Z.V., Serenko,V.P. 1990. Composition of continental upper mantle and lower crust beneath the Siberian platform. Nauka, Moscow (in Russian).

Spetsius, Z.V., Taylor, L.A., 2003. Partial melting in mantle eclogite xenoliths: evidence from Yakutian kimberlites. Intern. Geol. Rew. 11, 983-987.

Shulze, D.J, Walley. J.W., Spicuzza, M.J., 2000. Coesite eclogites from the Roberts Victor kimberlite, South
Africa. Lithos. 54(1), 23-32.mid-infrared spectra of diamonds. Intern. Geol. Rev., 37 (2), 95-110.

Contact Zdislav Spetsius, Institute of Diamond Industry, Lenin St. 39, Mirny, Yakutia, 678170, Russia, Email: Spetsius@yna.alrosa-mir.ru 